\title{
Usposobljenost za kakovosti pri menedžmentu projektov
}

\author{
Ladi Galjot* \\ Domel d.o.o., Otoki 21, 4228 Železniki, Slovenija \\ ladi.galjot@domel.com \\ Mirko Markič \\ Fakulteta za organizacijske študije v Novem mestu, Ulica talcev 3, 8000 Novo mesto, \\ Slovenija \\ mirko.markic@guest.arnes.si
}

\begin{abstract}
Povzetek:
Raziskovalno vprašanje (RV): Kakšna je usposobljenost sodelavcev za kakovost pri menedžmentu projektov?

Namen: Namen raziskave je bila empirična raziskava o usposobljenosti za kakovost z vidika metod, orodij ter tehnik pri menedžmentu projektov in podati predloge za izboljšanje stanja.

Metoda: Kvantitativno raziskavo smo izvedli med 164 zaposlenimi sodelavci v obravnavani organizaciji, ki so pristojni in odgovorni za izvajanje postopkov, ki so določeni s standardi sistemov menedžmenta kakovosti.

Rezultati: Ugotovljeno je bilo, da večina anketiranih pozna metode, orodja in tehnike kakovosti. Zaposleni z višjo stopnjo izobrazbe ne izkazujejo višje ocene poznavanja metod, orodij in tehnik kakovosti. Število let delovne dobe ne vpliva na število opravljenih usposabljanj.

Organizacija: Predlagali smo izboljšave, ki bodo koristne za vse tiste, ki skrbijo za planiranje, organiziranje, vodenje in kontroliranje izobraževanja ter usposabljanja na področju metod, orodij in tehnik kakovosti.

Družba: Pomembno je spodbujanje in podpora menedžmenta pri nadaljnjem izobraževanju ter usposabljanju zaposlenih, pridobivanju znanj in veščin, ki so temeljna vrednota ter konkurenčna prednost organizacij v družbenem okolju.

Originalnost: Največ usposabljanj je bilo za metode, orodja in tehnike, ki spadajo v pet stebrov kakovosti avtomobilske industrije (APQP, plan obvladovanja, FMEA, PPAP), poleg tega pa še 6 Sigma ter 8D.

Omejitve/nadaljnje raziskovanje: $\mathrm{V}$ raziskavi smo obravnavali zgolj poznavanje in mnenje o uporabnosti metod, orodij ter tehnik pri vgradnji kakovosti proizvod. Na podlagi rezultatov smo pripravili predloge za nadaljnje raziskovanje.
\end{abstract}

Ključne besede: menedžment, menedžment kakovosti, metode kakovosti, orodja kakovosti, podjetje, tehnike kakovosti, usposabljanje.

\section{Uvod}

V avtomobilski dobaviteljski verigi je vpeljava novega izdelka ali storitve (v nadaljevanju proizvoda) zahteven proces, ki zahteva vključenost zaposlenih, ki so usposobljeni za izpeljavo postopkov, ki jih predpisujejo standardi sistema menedžmenta kakovosti. Potrebna so stalna 
dodatna izobraževanja in usposabljanja zaposlenih. Usposobljeni zaposleni pripomorejo $\mathrm{k}$ razvoju kakovostnih proizvodov in učinkovitih procesov, ki organizaciji zagotavljajo konkurenčno prednost na tržišču.

Raziskovalni problem s katerim smo se v naši raziskavi soočali je bil proučitev poznavanja in izvajanja standardov sistemov menedžmenta kakovosti v proučevani organizaciji. Namen raziskave je bil proučiti v teoriji najpogosteje omenjene metode, orodja in tehnike kakovosti ter v praksi preveriti, ali jih v obravnavani organizaciji uporabljajo. Poglobili smo se predvsem v poznavanje metod, orodij in tehnik kakovosti, katera znanja so najpomembnejša, kje je znanje pomanjkljivo ter kje so potrebna dodatna usposabljanja.

Izvedli smo kvantitativno raziskavo o usposobljenosti za kakovost $\mathrm{z}$ vidika poznavanja metod, orodij in tehnik na cenzusu 164 zaposlenih sodelavcev, ki so sodelovali pri menedžmentu projektov v izbrani organizaciji ter zasnovali priporočila konkretnih izboljšav na področju usposobljenosti za kakovost iz vidika poznavanja metod, orodij in tehnik v izbrani organizaciji.

\section{Teoretična izhodišča}

Menedžment projektov je $\mathrm{v}$ današnjem času nujno potreben za obvladovanje tveganj, ob vpeljavi novega proizvoda (Brcar \& Markič 2017, str. 26). Menedžment projektov je uporaba znanja, veščin, tehnik in orodij $\mathrm{v}$ aktivnostih projekta za izpolnitev zahtev projekta (PMBOK 2008, str. 8). Anantatmula (2010, str. 3) ugotavlja, da številni dejavniki, ki vplivajo na uspešnost projekta, izhajajo iz človeškega dejavnika. Stare (2011, str. 40) definira menedžment projektov kot ciljno usmerjen dinamičen proces, ki vključuje obvladovanje časa, stroškov, kakovosti, ljudi in drugih prvin, z namenom učinkovite izvedbe projekta. Thomsett (2002, str. 72) navaja, da je bil tradicionalni pogled na uspešnost projekta določen z »železnim trikotnikom«. Projekt je bil uspešen, če so smotre in cilje projekta dosegli v dogovorjenem roku, v okviru planiranih stroškov ter pričakovani kakovosti (Markič Hrast \& Markič 2010, str. 68).

$\mathrm{V}$ avtomobilski industriji je varnost potrošnika na prvem mestu, zato je pomembno zagotavljanje kakovosti v vsej dobaviteljski verigi. Od vseh je zahtevana uporaba standardov kakovosti ISO in IATF 16949, ki zahtevajo dokazila o izvajanju metod, orodij ter tehnik kakovosti in uporabe orodij kakovosti. Naložbe $v$ doseganje kakovosti so čedalje večje in postanejo čedalje pomembnejša postavka $\mathrm{v}$ financiranju razvoja. Zahtevajo čedalje več časa in zmogljivosti, še posebej, če govorimo o zagotovitvi kakovosti procesov, kar se dokazuje s pridobitvijo certifikatov (Hauc 2017, str. 15). Sistem ISO za menedžment kakovosti je bil zasnovan kot skrbno pripravljen model dobre poslovne prakse v uspešnih organizacijah, ki ga lahko vsaka organizacija prenese k sebi z določenimi prilagoditvami (Piskar \& Dolinšek 2006, str. 14). Eno od temeljnih načel sodobnega menedžmenta kakovosti je »kakovost planiramo, zasnujemo in vgradimo - in ne kontroliramo «(PMBOK 2008, str. 184). Zato je pomembno, da so zaposleni usposobljeni za uporabo metod, orodij in tehnik kakovosti ter da so seznanjeni z zahtevami standardov, ki jih zahtevajo v avtomobilski industriji (Unterlechner, Štok \& Markič 2009, str. 27; VDA 2017, str. 6). 
Marolt in Gomišček (2005, str. 168) pravita, da bolj, ko so problemi kompleksni, večja je potreba po uporabi metod, orodij ter tehnik, s pomočjo katerih si pomagamo razumeti vzroke problema in bolje predstavljati dejansko situacijo.

V nadaljevanju predstavimo najpogosteje uporabljene metode, orodja in tehnike na področju menedžmenta kakovosti v avtomobilski industriji. Razdelili smo jih v tri skupine, glede na način obravnavanja problema. V skupino statističnih metod smo uvrstili tiste, ki do identifikacije problema pripeljejo s statistično obdelavo podatkov (6 Sigma, Measurement System Anylysis - MSA, kontrolne karte, Pareto diagram). Metode razrě̌evanja problemov v skupini so nestatistične metode, ki spodbujajo razmišljanje posameznika in pripeljejo do novih idej za razrešitev problema (Ishikawa ter viharjenje možganov). Metode preventivnega zagotavljanja kakovosti po predpisanih postopkih pripeljejo do izidov, ki preprečijo pojavitev napak v procesu (diagram poteka, Failure Mode and Effect Analysis - FMEA, metoda 8D, plan obvladovanja, Statistical Process Control - SPC). Z metodama kakovosti Advanced Product Quality Planning - APQP in Product Part Approval Process - PPAP na sistematičen način obvladujemo dokumente, ki so potrebni za celovit sistem menedžmenta kakovosti v projektu (Galjot 2020, str. 18).

V gospodarskih družbah oz. organizacijah so izvedene raziskave, na področju uvajanja standardov kakovosti in uvajanja sistemov menedžmenta kakovosti v organizacije (npr. Snedec 2010 \& Marko, 2013). Raziskave so usmerjenje v pregled zahtev standardov kakovosti, v metode za zagotavljanje kakovosti in vpliv teh na uspešnost organizacij. Veliko je raziskav z namenom ugotavljanja, ali zaposleni poznajo zahteve standardov, jih razumejo in izpolnjujejo zahteve. V vseh raziskavah je zaznati pozitiven vpliv vpeljave standardov kakovosti na poslovanje. Organizacije, ki uporabljajo standarde kakovosti, dosegajo večjo kakovost dobav, odzivnost dobaviteljev in točnost odprem. Markova (2013) je v raziskavi v izbrani organizaciji ugotovila, da zaposleni teoretično poznajo veliko metod, orodij in tehnik. V praksi se jih uporablja preveč in ker jih ne znajo v celoti izkoristiti, niso učinkovite. Tudi Debeljak (2017) poudarja pomembnost uvajanja standardov, ki zagotavljajo celovito in trajno obvladovanje tveganj. Pomembni vzvodi za širjenje zavesti so usposabljanja zaposlenih in sprotna ter stalna opozarjanja. Dolenec (2005) je v raziskavi učinkov vpeljave standardov v organizacijo zapisal, da je standard kakovosti bolj jasno definiral organizacijsko strukturo organizacije in izboljšal učinkovitost procesov.

Na podlagi opredelitve teoretičnih izhodišč, identificiranega problema in zaznane raziskovalne vrzeli, smo oblikovali ter preverili naslednje hipoteze:

H1: Zaposleni z višjo izobrazbo izkazujejo višjo stopnjo seznanjenosti z metodami, orodji in s standardi kakovosti.

H2: Delovna doba zaposlenega statistično značilno vpliva na število opravljenih usposabljanj s področja standardov kakovosti.

Raziskovalni problem, ki ga bomo v prispevku obravnavali, je bil proučitev poznavanja in izvajanja standardov sistemov menedžmenta kakovosti v proučevani organizaciji. Namen 
empirične analize je bil raziskati v teoriji najpogosteje omenjene metode, orodja in tehnike kakovosti ter v praksi preveriti, ali jih v obravnavani organizaciji uporabljajo. Poglobili smo se predvsem v poznavanje metod, orodij in tehnik kakovosti, katera znanja so najpomembnejša, kje je znanje pomanjkljivo ter kje so potrebna dodatna usposabljanja.

\section{Metoda}

V empiričnem delu raziskave smo opravili kvantitativno raziskavo, kot jo opisujejo EasterbySmith, Thorpe in Lowe (2007, str. 163). Kot pripomoček za pridobivanje primarnih podatkov smo uporabili vprašalnik. Easterby-Smith, Thorpe in Lowe (2007, str. 169) opredeljujejo kot glavni namen ankete pridobitev podatkov ter informacij s strani določenega kroga ljudi. Vprašalnik smo posredovali vsem zaposlenim na treh izbranih področjih (razvoj, tehnologija in kakovost), ki sodelujejo na projektih. Vprašalnik je bil dostopen na spletu v spletni aplikaciji 1KA. K sodelovanju smo jih povabili preko elektronske pošte. Anketiranci so odgovarjali anonimno.

Vprašalnik je bil sestavljen iz dveh delov. V prvem delu so se vprašanja nanašala na demografske podatke o anketirancu. Drugi del je vseboval vprašanja glede poznavanja metod, orodij in tehnik kakovosti ter opravljenih usposabljanjih s tega področja. Vprašanja smo oblikovali na podlagi podatkov, pridobljenih $\mathrm{v}$ teoretičnem delu raziskave. Vprašanja so zaprtega tipa $\mathrm{z}$ vnaprej pripravljenimi odgovori oziroma s trditvami na podlagi Likertove 5stopenjske lestvice ( 1 - sploh ne drži ..., 5 - popolnoma drži). V začetnem delu vprašalnika so respondenti opredelili, v katerem od treh področij, razvoj, kakovost ali tehnologija, so zaposleni. Z drugim vprašanjem so opredelili, ali večji del delovnega čas delajo na avtomobilskem programu ali na ostalih programih. Nato sta bila $v$ vprašalniku dva sklopa vprašanj s 13 podvprašanji. Nanašala so se na metode, orodja in tehnike kakovosti, ki so bile $\mathrm{v}$ teoretičnem delu magistrske naloge prepoznane kot najpogosteje uporabljene, oziroma je njihova uporaba določena s standardi. Pri vprašanju, ali poznajo naštete metode, orodja in tehnike kakovosti, so izbrali eden odgovor med naslednjimi možnimi: Zelo dobro - poznam pomen in uporabo postopka ter uporabljam pri delu, Dobro - poznam pomen in uporabo postopka, Povprečno - mi je poznano, vendar ne poznam postopka izvedbe, Sem že slišal - ne poznam postopka izvedbe, sem že slišal zanj ter Ne poznam. Pri vprašanju po mnenju o uporabnosti posamezne metode, orodja in tehnike pri vgradnji kakovosti v proizvod, je bilo možnih pet odgovorov: Zelo uporabna, Uporabna, Povprečna, Manj uporabna in Neuporabna. Pri petem vprašanju so anketiranci označili, katerih izobraževanj in usposabljanj so se udeležili ter katerih bi se želeli udeležiti v prihodnosti. Nato je bilo odprto vprašanje, kjer so anketiranci lahko napisali svoje predloge k povečanju usposobljenosti zaposlenih za kakovost. Zadnji del vprašalnika je vseboval vprašanja o demografskih podatkih: izobrazba, starost, delovna doba in spol. 


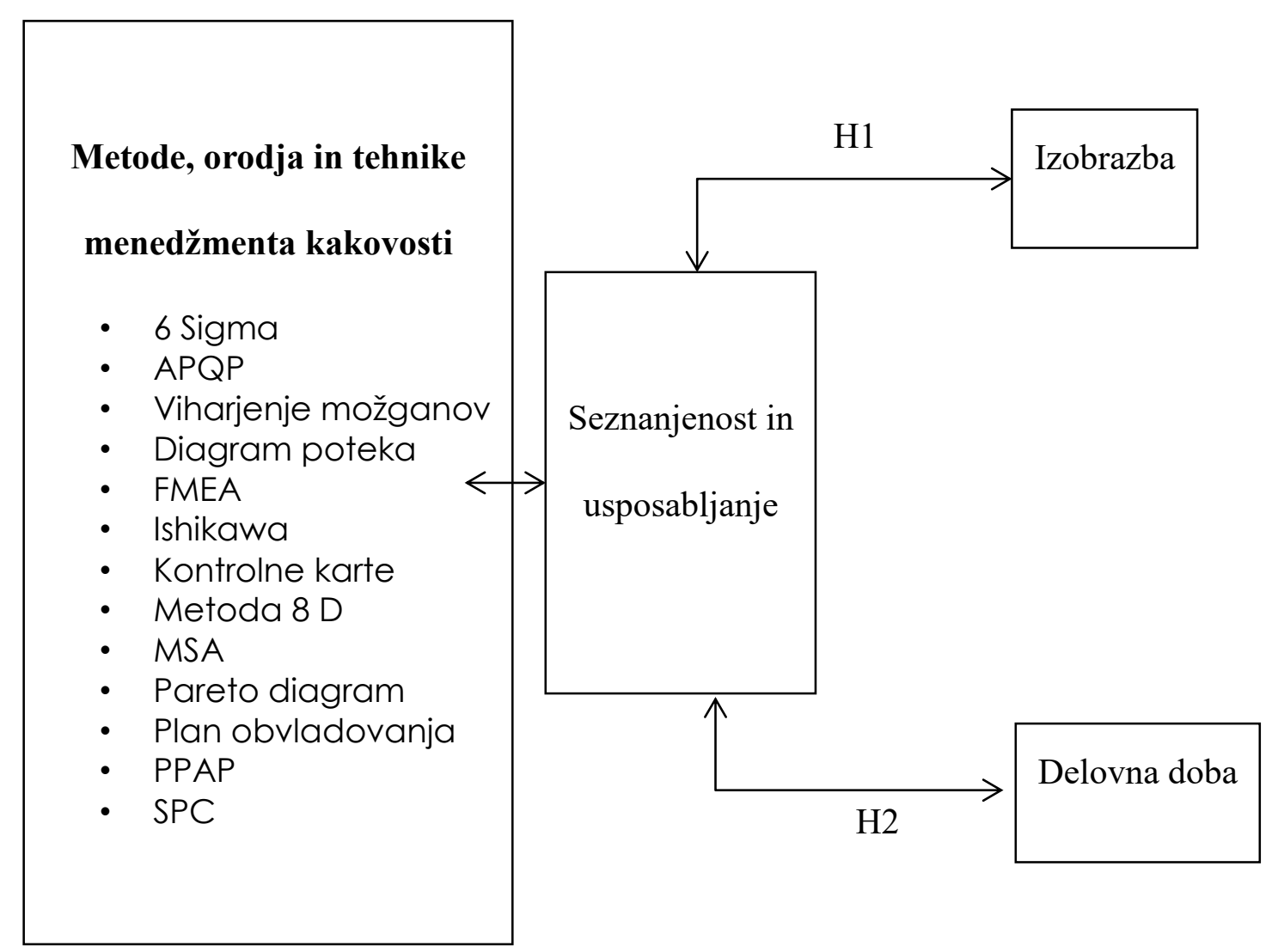

Slika 1. Model raziskave

Vprašalnik smo poslali na 164 elektronskih naslovov zaposlenih v oddelkih razvoj, kakovost in tehnologija. Anketiranje je bilo anonimno, vprašalnik je vseboval vprašanja zaprtega tipa, eno vprašanje je bilo odprtega tipa, z možnostjo vpisa mnenja. Anketiranje smo izvedli na populaciji zaposlenih v oddelkih razvoj, kakovost in tehnologija v obravnavani organizaciji. Vključeni so bili vsi zaposleni iz teh treh oddelkov, saj so v teh službah pristojni in zadolženi za izvajanje postopkov, ki jih predpisujejo standardi ter morebitne dodatne zahteve potrošnikov. V teh oddelkih nastaja razvojna, tehnološka in kontrolna dokumentacija. Uporaba metod, orodij in tehnik se začne že v samem začetku razvoja novega proizvoda, da se razvije proizvod, ki bo ustrezal potrebam potrošnika ter ga bo možno izdelovati v zahtevani kakovosti v pogojih serijskega proizvajanja. Tudi pri razvoju procesa in postavitvi tehnologije je potrebna uporaba metod, orodij ter tehnik, da se zagotovi proces, ki je sposoben proizvod zagotavljati $\mathrm{v}$ zahtevanih količinah in predpisani kakovosti, s čim nižjimi stroški, s čim manj zastojev in brez izmeta. Prav tako je oddelek kakovosti vključen v razvoj proizvoda in procesa, pripravlja plan obvladovanja, standarde kakovosti ter merilno opremo za izdelavo prototipov in za serijsko proizvajanje.

Podatke smo analizirali, obdelali in interpretirali v spletnem programu za izvedbo anket $1 \mathrm{KA}$ ter v programskem orodju Microsoft Excel. 


\section{Rezultati in razprava}

\subsection{Demografski podatki anketiranih}

Vprašalnik je bil poslan na 164 elektronskih naslovov. Vrnjenih smo dobili 162 izpolnjenih anket. Vse niso bile izpolnjene v celoti, zato smo jih izločili. V analizo smo vključili $127 \mathrm{v}$ celoti izpolnjenih anket, to je $77 \%$ odzivnost celotnega vzorca, ki je skladna s pričakovanji za družboslovno raziskovanje (Flere 2000, str. 34). Vprašalnik je bil poslan zaposlenim iz obravnavane organizacije, ki delajo v razvoju, kakovosti in tehnologiji. Demografski podatki o starosti, delovni dobi, izobrazbi in delovni dobi so predstavljeni v Tabeli 1. 
Tabela 1: Število anketirancev po spolu, starosti, delovni dobi in izobrazbi

\begin{tabular}{|c|c|c|}
\hline Spol & Frekvenca & Delež $(\%)$ \\
\hline Moški & 103 & 81,1 \\
\hline Ženski & 24 & 18,9 \\
\hline Skupaj & 127 & 100 \\
\hline \multicolumn{3}{|l|}{ Starost } \\
\hline do 20 let & 0 & 0,0 \\
\hline 21-30 let & 28 & 22,1 \\
\hline $31-40$ let & 45 & 35,4 \\
\hline $41-50$ let & 30 & 23,6 \\
\hline $51-60$ let & 23 & 18,1 \\
\hline 61 let ali več & 1 & 0,8 \\
\hline Skupaj & 127 & 100 \\
\hline \multicolumn{3}{|l|}{ Delovna doba } \\
\hline do 10 let & 48 & 37,8 \\
\hline 11-20 let & 26 & 20,5 \\
\hline $21-30$ let & 25 & 19,7 \\
\hline Nad 31 let & 28 & 22,0 \\
\hline Skupaj & 127 & 100 \\
\hline \multicolumn{3}{|l|}{ Izobrazba } \\
\hline Srednješolska izobrazba & 19 & 14,9 \\
\hline Višješolska izobrazba & 26 & 20,5 \\
\hline Visokošolska izobrazba & 33 & 26,0 \\
\hline Univerzitetna izobrazba & 31 & 24,4 \\
\hline Magisterij & 12 & 9,5 \\
\hline Doktorat & 6 & 4,7 \\
\hline Skupaj & 127 & 100 \\
\hline
\end{tabular}

V raziskavi je sodelovalo $81,1 \%$ moških in 18,9 \% žensk. Največji delež sodelujočih v raziskavi je starih od 31 do 40 let $(35,4 \%)$ in od 41 do 50 (23,6 \%). Nihče ni bil mlajši od 20 let, eden $(0,8 \%)$ je bil star več kot 61 let. V vzorcu je bil največji delež zaposlenih z do 10 let delovne dobe $(37,8 \%)$, ostala populacija se je enakomerno porazdelila $\mathrm{v}$ preostala starostna obdobja. Največ respondentov ima visokošolsko izobrazbo (26,0 \%), najmanj pa doktorat $(4,7 \%)$. 


\subsection{Poznavanja metod, orodij in tehnik}

Pri prvem vprašanju smo anketirane vprašali, koliko poznajo posamezne metode, orodja in tehnike kakovosti. V Tabeli 2 so predstavljene osnovne statistike o poznavanju metod, orodij in tehnik.

Tabela 2. Poznavanje metod, orodij in tehnik

\begin{tabular}{lrrrr} 
Poznavanje metode & Povprečje & Modus & Mediana & $\begin{array}{r}\text { Standardni } \\
\text { odklon }\end{array}$ \\
\hline 6 sigma & 3,2 & 3 & 3 & 0,98 \\
APQP & 2,97 & 4 & 3 & 1,26 \\
Viharjenje možganov & 3,63 & 4 & 4 & 1,23 \\
Diagram poteka & 3,77 & 5 & 4 & 1,19 \\
FMEA & 3,9 & 4 & 4 & 1,07 \\
Isikawa & 2,97 & 4 & 3 & 1,37 \\
Kontrolne karte & 3,14 & 3 & 3 & 1,26 \\
Metoda 8D & 3,75 & 5 & 4 & 1,15 \\
MSA & 3,2 & 4 & 3 & 1,31 \\
Pareto diagram & 2,92 & 3 & 3 & 1,33 \\
Plan obvladovanja & 4,03 & 5 & 4 & 1,1 \\
PPAP & 3,83 & 4 & 4 & 1,16 \\
SPC & 2,87 & 1 & 3 & 1,45
\end{tabular}

Iz zgornje tabele so razvidne povprečne vrednosti, ki prikazujejo, da so anketirani v povprečju opredelili večjo vrednost od 2,87. Največja povprečna vrednost $(4,03)$ je pri poznavanju plana obvladovanja, najnižja povprečna vrednost $(2,87)$ pri metodi SPC.

Standardni odklon kaže, da so ocene poznavanja najbolj razpršene pri poznavanju metode SPC in najmanj pri poznavanju 6 sigme.

Da bi preverili, koliko zaposleni poznajo metode, orodja in tehnike kakovosti, smo najprej pogledali splošno stanje. Na Sliki 2 je prikazana povprečna ocena poznavanja metod, orodij in tehnik v izbrani organizaciji. Anketirani najbolj poznajo plan obvladovanja (ocena 4,03), najmanj pa SPC $(2,87)$. Dobro poznajo tudi FMEA, PPAP, diagram poteka, 8D, viharjenje možganov. Med manj poznanimi so 6 sigma, MSA, kontrolne karte, APQP, Ishikawa in Pareto diagram. Pri 6 sigma je najmanjši standardni odklon $(0,89)$, ki z ocenami med 3,15 in 3,25 kaže, da jo v vsi poznajo približno enako. Največji standardni odklon je 1,45 pri metodi SPC. Povprečna ocena je nizka (2,87). V razvoju so ocenili z 2,11, v kakovosti s 3,64. Visok standardni odklon je posledica specifičnosti te metode, ki se jo uporablja za analizo sposobnosti merilnih sistemov, ki jo izvaja oddelek kakovosti. 


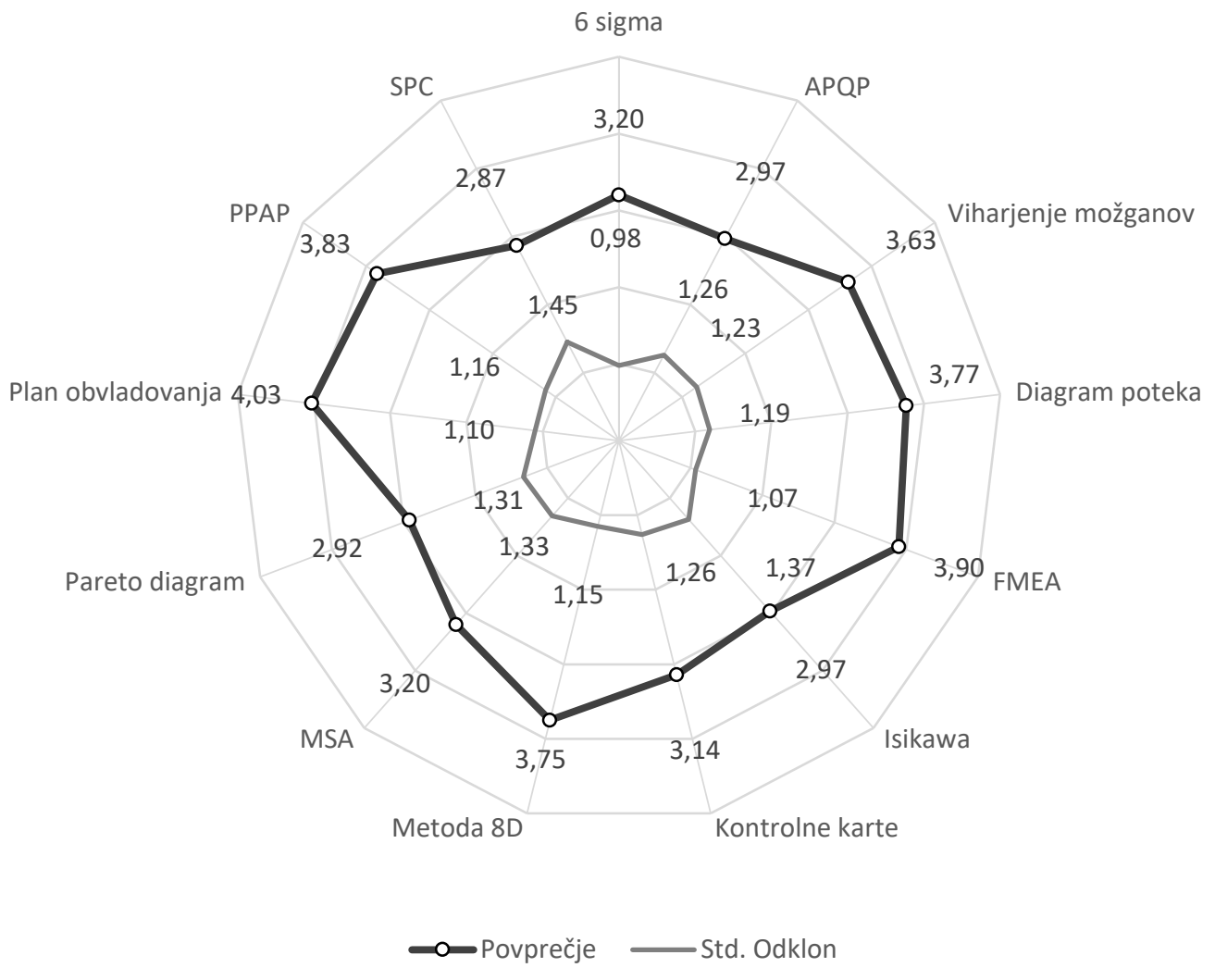

Slika 2. Poznavanje metod, orodij in tehnik kakovosti

\subsection{Uporabnost metod, orodij in tehnik kakovosti}

Pri drugem vprašanju smo anketirane vprašali po mnenju o uporabnosti posamezne metode, orodja ali tehnike pri vgradnji kakovosti v proizvod. 


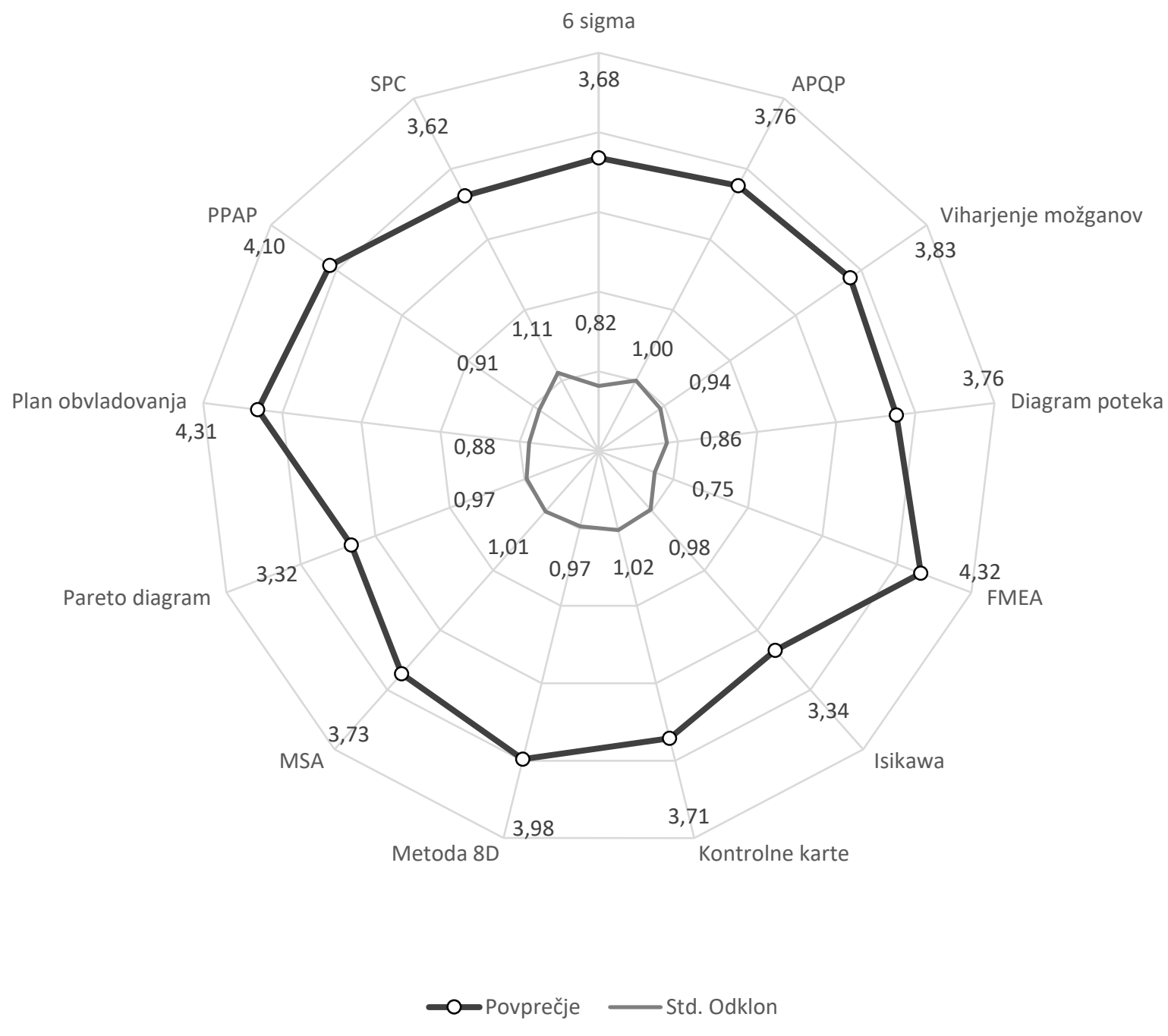

Slika 3. Ocena uporabnosti metod, orodij in tehnik kakovosti

Zanimalo nas je mnenje anketirancev, koliko metode, orodja in tehnike pripomorejo pri vgradnji kakovosti v proizvod. Na Sliki 3 so prikazane povprečne ocene za celotno populacijo. Anketiranci se strinjajo, da so vse zelo uporabne pri zagotavljanju kakovostnih proizvodov. Najvišjo oceno so podali FMEA (4,32), planu obvladovanja $(4,31)$, PPAP $(4,1)$, sledijo metoda $8 \mathrm{D}$, viharjenje možganov, APQP, diagram poteka, MSA, kontrolne karte, 6 sigma, SPC (ocene od 3,98 do 3,62). Po mnenju večine anketiranih k vgradnji kakovosti v proizvod najmanj doprineseta Isikawa $(3,34)$ in Pareto diagram $(3,32)$.

Mnenja o uporabnosti posamezne metode, orodja ali tehnike pri vgradnji kakovosti v proizvod ne odstopajo v tolikšni meri, kot so pri odgovorih na vprašanje o njihovem poznavanju. Najnižji standardni odklon je pri oceni uporabnosti metode FMEA. Nihče je ni ocenil kot neuporabno, kot manj uporabno pa 1,5\%. 48 \% jo je ocenilo kot zelo uporabno. Največji standardni odklon je pri metodi SPC (1,11). Tu je velika razlika med razvojem, kjer jih $10 \%$ meni, da ni uporabna, in kakovostjo, kjer jih 40,9\% meni, da je zelo uporabna. 


\subsection{Preverjanje hipotez}

H1: Zaposleni z višjo izobrazbo izkazujejo višjo stopnjo seznanjenosti z metodami, orodji in s tehnikami kakovosti.

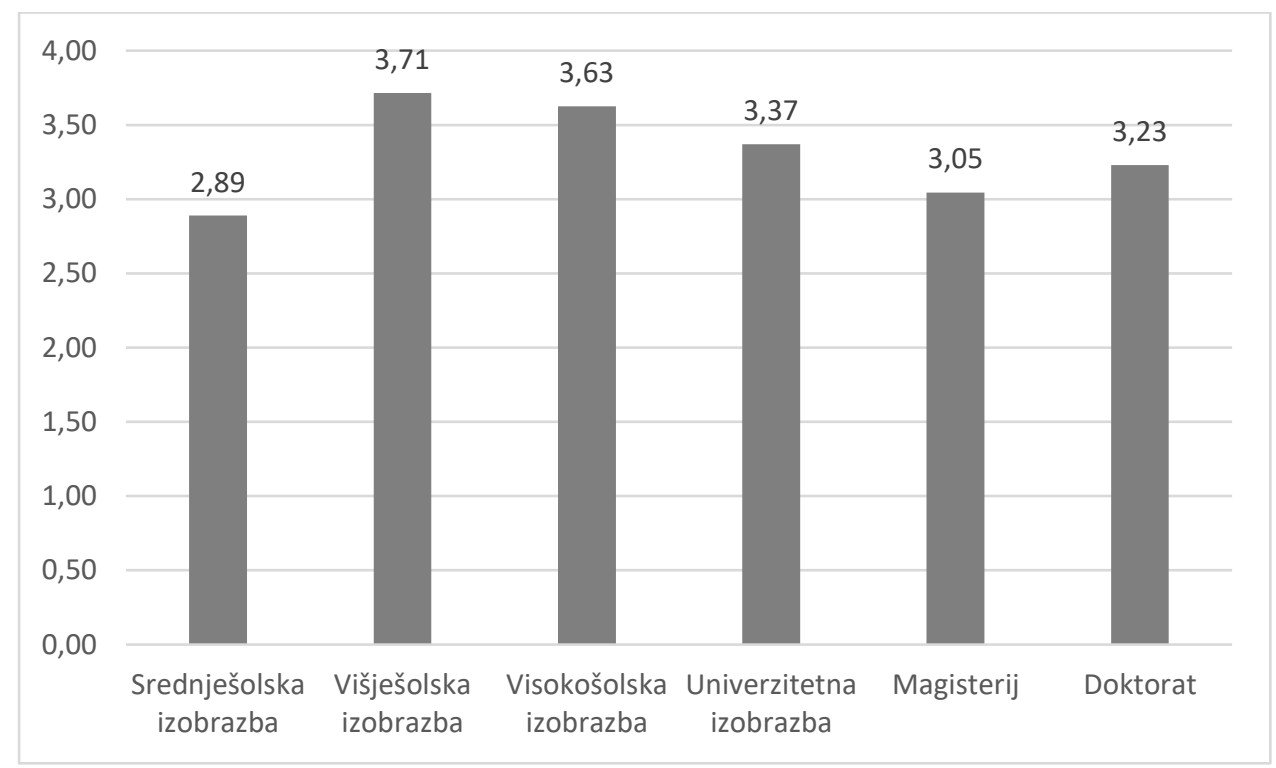

Slika 4. Povprečje ocene poznavanja metod, orodij in tehnik glede na izobrazbo

V grafu na Sliki 4 je prikazano poznavanje metod, orodij in tehnik glede na izobrazbo. Najvišja povprečna ocena poznavanja vseh metod, orodij in tehnik je izračunana pri zaposlenih z višješolsko izobrazbo $(3,71)$, sledi višješolska izobrazba $(3,63)$, univerzitetna izobrazba $(3,37)$ ter doktorat $(3,23)$. S slike je razvidno, da poznavanje metod, orodij in tehnik kakovosti ni pogojeno z višino stopnje izobrazbe. To je kazalnik, da poznavanje metod, orodij in tehnik ni pridobljeno s formalno izobrazbo, ampak je pridobljeno z delovnimi izkušnjami ter dodatnim usposabljanjem glede na potrebe delovnega mesta.

Hipoteze 1 ne potrdimo, saj zaposleni $\mathrm{z}$ višjo stopnjo izobrazbe ne izkazujejo višje ocene poznavanja metod, orodij in tehnik kakovosti.

H2: Delovna doba zaposlenega vpliva na število opravljenih usposabljanj s področja standardov kakovosti.

Za preverjanje hipoteze smo izračunali povprečno število opravljenih usposabljanj na zaposlenega in jih razvrstili glede na število let delovne dobe. Na Sliki 5 je prikazano, da so največ usposabljanj opravili anketirani, ki imajo med 21 in 30 let delovne dobe, povprečno 3,62. Sledijo jim anketirani z več kot 31 let delovne dobe, ki so opravili 3,48 usposabljanj na posameznika. Anketirani z do 10 let delovne dobe so opravili 3,35 usposabljanj. Najmanj usposabljanj je bilo v skupini anketiranih $\mathrm{z}$ od 11 do 20 let delovne dobe, to je le 2,62 usposabljanj na posameznika. 
Hipotezo 2 zavrnemo. Število let delovne dobe ne vpliva na število opravljenih usposabljanj.

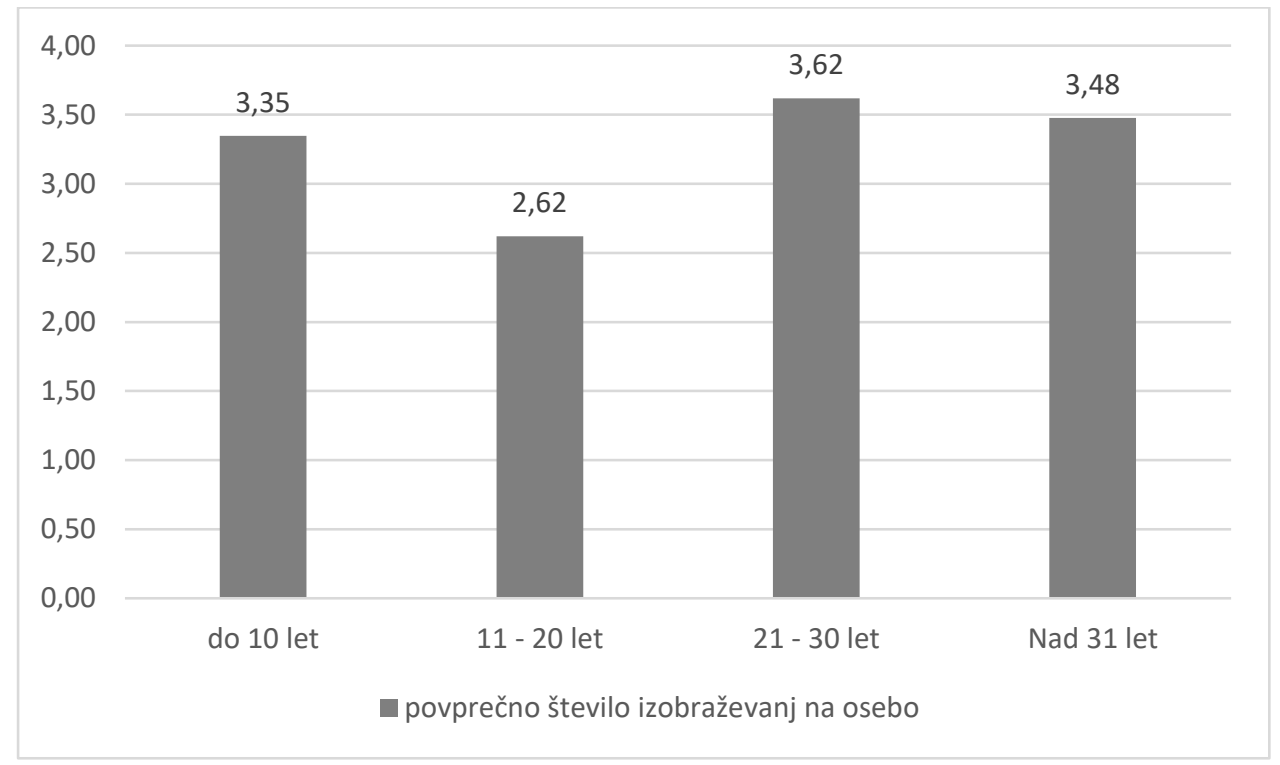

Slika 5. Opravljena usposabljanja glede na delovno dobo

\section{Zaključek}

$\mathrm{V}$ empiričnem delu raziskave smo v izbrani organizaciji opravili anketo o poznavanju metod, orodij in tehnik za menedžment kakovosti, ki so določene s standardom IATF 16949. Najprej smo preverili, koliko anketirani poznajo metode, orodja in tehnike, ki predstavljajo pet stebrov kakovosti v avtomobilski dejavnosti. APQP, PPAP, FMEA in plan obvladovanja so v celotnem povprečju dobile visoko oceno poznavanja. SPC in MSA v celotnem povprečju nista dosegli visoke ocene, saj jih uporablja le del zaposlenih. To sta specifični metodi, ki se ju uporablja za preverjanje stabilnosti merilnih procesov in analizo sposobnosti procesov. Uporabljajo ju v oddelku kakovosti, kjer je ocena poznavanja precej višja kot v razvoju. V njihovo izvedbo so delno vključeni tudi zaposleni v tehnologiji, kar se kaže tudi pri višji oceni. Podobni izidi so bili ugotovljeni tudi pri oceni njihove uporabnosti pri vgradnji kakovosti v proizvod. V povprečju so bile ocene uporabnosti višje od ocene poznavanja, kar nakazuje na zavedanje zaposlenih, da so metode, orodja in tehnike uporabne ter bi jih izvajali v večji meri, če bi jih znali pravilno izvajati in uporabljati.

Pri raziskavi poznavanja metod, orodij in tehnik glede na stopnjo dosežene izobrazbe, je bilo ugotovljeno, da zaposleni z višjo stopnjo izobrazbe ne izkazujejo višje stopnje njihovega poznavanja. Rezultati so pokazali, da jih najbolje poznajo zaposleni z višješolsko izobrazbo, manj pa zaposleni $z$ visokošolsko izobrazbo. To nakazuje, da se jih ne naučijo v formalnem izobraževanju, temveč $z$ dodatnim usposabljanjem za potrebe delovnega mesta. Pri mnenju o uporabnosti metod, orodij in tehnik za vgradnjo kakovosti v proizvod ni bilo večjih razlik med zaposlenimi, razdeljenimi glede na stopnjo izobrazbe. Rezultati so pokazali, da so se udeležili največ usposabljanj za metode, orodja in tehnike, ki spadajo $\mathrm{v}$ pet stebrov kakovosti 
avtomobilske industrije (APQP, plan obvladovanja, FMEA, PPAP), poleg tega pa še 6 Sigma ter 8D. Največ zanimanja je za dodatna usposabljanja APQP, PPAP in FMEA.

Zaposleni v podjetju dobro poznajo metode, orodja in tehnike kakovosti. Prav tako se zavedajo njihove uporabnosti pri vgradnji kakovosti v proizvod. Glede na razliko v indikatorju Likertove lestvice pri oceni poznavanja in mnenju o njihovi učinkovitosti, predvidevamo, da se zaposleni zavedajo pomanjkanja usposobljenosti za izvajanje metod, orodij ter tehnik. Naši izidi se v celoti ujemajo z izidi Markove (2013), ki je v raziskavi v izbrani organizaciji ugotovila, da zaposleni teoretično poznajo veliko metod, orodij in tehnik kakovosti. Investiranje v kakovost zahteva čedalje več časa in virov, še posebej, če govorimo o zagotovitvi kakovosti procesov, kar se dokazuje s pridobitvijo certifikatov (Hauc 2017, str. 15).

V empiričnem delu smo raziskali usposobljenost zaposlenih v oddelkih razvoj, kakovost in tehnologija v izbrani organizaciji. Izidi raziskave so pokazali, da zaposleni poznajo metode, orodja in tehnike kakovosti ter jih uporabljajo pri svojem delu. Strinjajo se, da pripomorejo k vgradnji kakovosti v izdelek in proces. V nekaterih skupinah zaposlenih se kaže pomanjkanje usposobljenosti, zaznana je nizka zainteresiranost za dodatna usposabljanja. V raziskavi smo ovrgli hipotezo, da je število usposabljanj pri anketiranih z več let delovne dobe večje kot pri ostalih z manj let delovne dobe. Povprečno število usposabljanj na posameznika z leti res raste, vendar se to $\mathrm{v}$ raziskavi ni potrdilo, saj se je zaradi hitre rasti podjetja, predvsem na avtomobilskem programu, $\mathrm{v}$ zadnjih desetih letih zelo povečalo število novo zaposlenih, ki so zaradi potreb delovnega mesta opravili več usposabljanj. Tako je bilo povprečno število usposabljanj na posameznika $\mathrm{v}$ skupini anketiranih $\mathrm{z}$ delovno dobo do deset let večje kot pri skupini z delovno dobo od 11 do 20 let.

Zasnovali smo predloge za izboljšanje stanja, ki bodo imeli praktične koristi za obravnavano organizacijo in koristne informacije za vse tiste, ki se ukvarjajo z uvajanjem metod, orodij ter tehnik kakovosti v podjetja in druge ustanove.

Raziskava je bila izvedena $\mathrm{z}$ naslednjimi predpostavkami: Pridobivanje podatkov s pomočjo vprašalnika je najprimernejši način za izvedbo kvantitativne raziskave. Zaposleni v razvoju, tehnologiji in kakovosti so ključni pri uvajanju ter uporabljanju metod, orodij in tehnik kakovosti, zato so najprimernejša populacija za to raziskavo. Vključeni v projektne time lahko najbolje ocenijo stanje poznavanja standardov kakovosti v organizaciji.

Omejitve pri obravnavanju problema so bile naslednje: Kakovost raziskave je bila odvisna od pripravljenosti anketirancev za sodelovanje $\mathrm{v}$ anketi in povzema subjektivno oceno anketirancev. Zbiranje podatkov $\mathrm{z}$ vprašalnikom, kjer prevladujejo vprašanja zaprtega tipa $\mathrm{z} \mathrm{V}$ naprej pripravljenimi odgovori, so lahko slabost, saj je vedno podano le omejeno število odgovorov. Vendar pa je uporaba vprašanj zaprtega tipa najprimernejša za kvantitativno raziskavo.

V raziskavi smo obravnavali zgolj poznavanje in mnenje o uporabnosti metod, orodij ter tehnik pri vgradnji kakovosti v proizvod. Smiselno bi bilo raziskati razloge za nezainteresiranost 
zaposlenih za dodatna usposabljanja. Predlagamo podrobnejšo raziskavo o opravljenih usposabljanjih, v kateri bi pridobili natančnejše podatke o opravljenih usposabljanjih, o izvajalcih usposabljanj in oceno njihove kakovosti izvedbe. Predlagamo raziskavo, s katero bi preverili ponudbo strokovnih izobraževanj in kakovost ponudnikov usposabljanj za izvajanje metod, orodij ter tehnik kakovosti. Standardi kakovosti organizaciji prinašajo prednosti in slabosti. Prednosti se kažejo $\mathrm{v}$ sodelovanju s potrošniki $\mathrm{v}$ avtomobilski industriji, ki so pripravljeni investirati $\mathrm{v}$ razvoj in opremo, slabosti pa so $\mathrm{v}$ povečanih stroških zaradi vzdrževanja zahtev standardov. Teh stroškov se v obravnavani organizaciji ne nadzoruje ločeno, so strošek projekta uvedbe novega proizvoda $v$ proizvajanje. Zaradi tega jih je težje identificirati in ukrepati za njihovo znižanje. Predlagamo raziskavo, kjer bi se identificiralo in ovrednotilo dodatne stroške zaradi zahtev standardov. Menedžerji bi imeli natančnejše informacije, do kolikšne vrednosti sofinanciranja $\mathrm{v}$ investicijo je projekt še donosen za organizacijo. Taka raziskava bi menedžerjem prinesla koristne informacije pri odločanju za nove projekte.

\section{Reference}

1. Anantatmula, V. S. (2010). Project Manager Leadership Role in Improving Project Performance. Engineering Management Journal 22 (1), 3-8.

2. Brcar, M. \& Markič, M. (2017). Menedžment projektov in finančna dodana vrednost. Revija za univerzalno odličnost 6 (1), 25-38.

3. Debeljak, Č. (2017). Prenova procesa poslovanja, skladna s smernicami standardov vedenja kakovosti. Magistrsko delo. Univerza v Ljubljani, Ekonomska fakulteta.

4. Dolenec, M. (2005). Vpeljava standarda kakovosti ISO 9001:2001 v podjetje Kovinar Jesenice in ocena učinkov pridobitve standarda. Magistrsko delo. Univerza v Ljubljani, Ekonomska fakulteta.

5. Easterby-Smith, M., Thorpe, R. \& Lowe, A. (2007). Raziskovanje v managementu. Koper: Univerza na Primorskem, Fakulteta za management.

6. Flere, S. (2000). Sociološka metodologija. Maribor: Univerza v Mariboru, Pedagoška fakulteta.

7. Galjot, L. (2020). Usposobljenost za kakovost pri managementu projektov v izbranem podjetju: Magistrska naloga. Koper: Univerza na Primoskem, Fakulteta za management.

8. Hauc, A. (2007). Projektni management. Ljubljana: GV Založba.

9. IATF 16949, Automotive Quality Management System Standard, 2016.

10. IATF Auditor Guide for IATF 16949, 4th Edition, 2019, AIAG.

11. Markič Hrast, S. \& Markič, M. (2010). Management projektov v zavodih za zdravstveno varstvo. Organizacija 43 (2), A67-A77.

12. Marko, T. (2013). Sistem vodenja kakovosti z metodami zagotavljanja kakovosti. Magistrska naloga. Maribor: Univerza v Mariboru, Fakulteta za logistiko.

13. Marolt, J. \& Gomišček, B. (2005). Management kakovosti. Kranj: Moderna organizacija.

14. Piskar, F. \& Dolinšek, S. (2006). Učinki standarda kakovosti ISO: od managementa kakovosti od poslovnega modela. Koper: Univerza na Primorskem, Fakulteta za Management.

15. PMBOK. (2008). Vodnik po znanju projektnega vodenja. PMBOK vodnik. Kranj: Moderna organizacija 
16. Snedec, B. (2010). Učinki standarda kakovosti ISO 9001: študija primera. Magistrska naloga. Koper: Univerza na Primorskem, Fakulteta za Management

17. Stare, A. (2011). Projektni management: teorija in praksa. Ljubljana: Agencija Poti.

18. Thomsett, R. (2002). Radical project management. Upper Saddle River (NJ): Prentice Hall PTR

19. Unterlechner, M., Štok, M.Z. \& Markič, M. (2009). Inoviranje, kakovost in Lean Six Sigmav v proizvodnem procesu. Koper: Univerza na Primorskem, Fakulteta za management.

20. VDA. 2017. Quality Management in the Automotive Industry: Assesment of Quality Management Methods, Guideline. Online-document. Verband der Automobilindustrie. Quality Management Center. Berlin. Pridobljeno na http://www.vda-qmc.de/publikation/download.

Ladi Galjot je diplomirala na Fakulteti za menedžment Univerze na Primorskem na temo Psihološka pogodba zaposlenih v času gospodarske krize. Na isti fakulteti je končala magisterij na temo Usposobljenosti zaposlenih za kakovost pri managementu projektov. Zaposlena je v podjetju Domel, v oddelku Razvoj in raziskave. Je vodja projektov za razvoj motorjev in motornih komponent.

$$
* * *
$$

Mirko Markič je doktoriral na Fakulteti za organizacijske vede Univerze v Mariboru s področja organizacijskih ved na temo inoviranja. Po dvanajstih letih delovanja v gospodarstvu se je zaposlil na Fakulteti za menedžment Univerze na Primorskem. Je redni profesor za področje menedžmenta in znanstveni svetnik ter vodja ali član 17 raziskovalnih projektov in projektov z gospodarstvom. Njegova bibliografija obsega več kot 650 enot s področja upravnih in organizacijskih ved ter javnega zdravstva (varstvo pri delu).

\section{Abstract: Skills for Quality in the Project Management}

Research Question (RQ): What are the skills of employees for quality in the project management? Purpose: The aim of the research was to conduct an empirical research about the skills for quality from the view of methods, tools, and techniques on project management and give suggestions for improvement of current state.

Method: Quantitative research was conducted on 164 employees in the organisation, which are competent and responsible for implementation of procedures defined by quality management system standards.

Results: It was found out that most of the respondents know the quality methods, tools and techniques. Employees with a higher level of education do not show the higher level of knowledge of the quality methods, tools, and techniques. The number of years of service does not affect the number of completed trainings.

Organization: We proposed the improvements that will be useful for all those who take care of planning, organizing, leading and controlling education and training in the field of quality methods, tools, and techniques.

Society: It is important to encourage and support management in further education and training of employees, acquiring knowledge and skills that are a fundamental value and the competitive advantage of organizations in the social environment.

Originality: Most of the training was performed for the methods, tools, and techniques that belong into the five pillars of quality of the automotive industry (APQP, control plan, FMEA, PPAP), in addition to the 6 sigma and to the $8 \mathrm{D}$. 
Revija za univerzalno odličnost / Journal of Universal Excellence,

September 2021, leto / year 10, številka / number 3, str. / pp. 217-232.

Limitations/Future Research: We considered only the knowledge and opinion on the applicability of methods, tools, and techniques in the implementation of quality in product. We prepared the proposals for further research.

Keywords: enterprise, management, quality management, quality methods, quality techniques, quality tools, training.

Copyright (c) Ladi GALJOT, Mirko MARKIČ

\section{(c) (1) ()}

Creative Commons License

This work is licensed under a Creative Commons Attribution-ShareAlike 4.0 International License. 